\title{
THE STRENGTH OF CORROSIVE PROPERTIES OF CRUDE OILS ON FERROUS METALS
}

\author{
Suresh Aluvihara \\ Department of Chemical and Process Engineering \\ University of Peradeniya \\ Kandy, Central Province, Peradeniya, Sri Lanka, KY20400 \\ sureshaluvihare@gmail.com \\ Jagath K. Premachandra \\ Department of Chemical and Process Engineering \\ University of Moratuwa \\ Katubedda, Sri Lanka, 10400 \\ bajagathp@gmail.com
}

\begin{abstract}
Crude oil is an unrivaled earth resource for the most of industrial applications. In the refining process of crude oil, ferrous metals play a severe role against the harsh environment while confronting adverse influences of crude oils such as the corrosion of ferrous metals. The formation of metal oxides, sulfides, hydroxides or any compound related with carboxylic group on the metal surface is known as the corrosion also mainly depends on the sulfur content, acidity, salt content and mercaptans content of relevant crude oils as well as the chemical composition of the metal. In this research it was expected to speculate the effect of such corrosive properties of Murban and Das Blend crude oils on seven different types of ferrous metals which are used in crude oil refining industry of Sri Lanka. The sulfur content, salt content, acidity and mercaptans content of each crude oil were determined by the succession of XRF analyzer, analyzer of salt and titration methods. A range of similar sized pieces of seven different types of ferrous metals were immersed in both crude oils separately and their corrosion rates were determined after 15, 30 and 45 days from the immersion by the weight loss method while observing the corroded metal surfaces under the optical microscope. The metallic concentrations in both crude oil samples after the experiment were tested by the AAS. It was found that the higher content of sulfur, acidity, mercaptans and lower content of salt in the Das blend than the Murban. According to the corrosion rates of metals, four types of metals showed higher rate of corrosion in Murban while other metals are showing higher corrosion rate in Das blend also higher metallic concentrations were obtained from Murban crude oil samples than Das Blend crude oil samples in the analysis of the AAS.
\end{abstract}

Keywords: Murban, Das Blend, corrosive properties, ferrous metals, weight loss, corrosion.

\section{Introduction}

In the industry of crude oil refining, there are vast applications of ferrous metals. The corrosion is much considerable phenomenon that due to the corrosive properties of crude oils and also the corrosive tendencies of ferrous metals [1-5]. When the exposure of metals either strong oxidizing agent than $\mathrm{Fe}^{2+}$ or any environment that consist water and oxygen while the catalytic effect of salts and organic acids present in the medium [2-9]. The formation of metal oxides, sulfides and or hydroxides on the metal surface is known as the corrosion. Usually crude oil is a mixture of hydrocarbons which are known as non-corrosive compounds. However due to the presence of some specific compounds cause the metallic corrosion in different ways. The content of sulfur, mercaptans, acidity and content of salt are the foremost corrosive properties that found in crude oils. The mixture of $\mathrm{NaCl}, \mathrm{MgCl}_{2}$ and $\mathrm{CaCl}_{2}$ is considered as the overall salt content in the relevant crude oil [7-15]. The raw crude oil may consist with those compounds and also some insignificant amount of water. In the current research, it was expected to investigate the effect of corrosive properties of crude oils on the rate of corrosion in seven different types of ferrous metals that used often in the industry of crude oil refining in Sri Lanka.

\section{Materials and Methodology}

\section{1. Materials}

In this research, two different types of crude oils were selected that recently used in the Sri Lanka crude oil refining industry. Murban and Das Blend were both of selected crude oils and 
those are different in the chemical composition and properties. According to the metal samples, seven different types of metals were selected including three types of carbon steel, three types of stainless steel and Monel which is consisted trace amount of iron [1,3]. The shape and dimensions of each metal was prepared as equal in the size because of the comparison.

\section{2. Methodology}

The corrosive properties of crude oils were determined separately with respect to the both crude oils based on the assumptions of neglecting the effect of the change of environmental parameters such as the temperature. The methodologies of testing such properties are given in the Table $\mathbf{1}$.

\section{Table 1}

Testing of the corrosive properties of crude oils

\begin{tabular}{cccc}
\hline Property & Procedure and instruments & Readings \\
Sulfur content & $\begin{array}{c}\text { Directly tested by XRF Analyzer } \\
\text { Samples were dissolved in organic } \\
\text { solvent and exposed to the cell of the } \\
\text { analyzer of salt }\end{array}$ & Direct readings \\
Acidity & $\begin{array}{c}\text { Samples were dissolved in a mixture of } \\
\text { toluene and isopropyl and titrated with } \\
\text { potassium hydroxide }\end{array}$ & Direct readings \\
Mercaptans content & $\begin{array}{c}\text { Samples were dissolved in sodium ace- } \\
\text { tate and titrated with silver nitrate }\end{array}$ & End point of the titration
\end{tabular}

The chemical compositions of selected ferrous metals were tested by the XRF detector. Three metal pieces from each metal type were completely immersed in a beaker with respect to both crude oils separately. A setup of samples that used in the experiment is given in the Fig.1, 2.

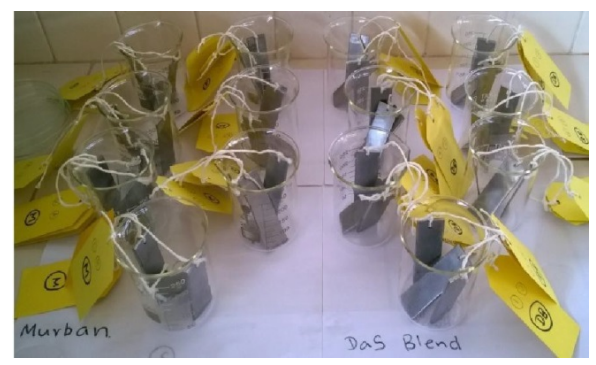

Fig. 1. Prepared metal samples

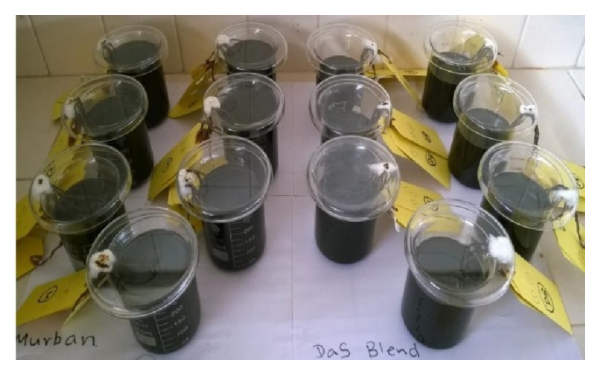

Fig. 2. Apparatus setup

After 15 days from the immersed day, a piece of metal was taken out from each beaker as representing each metal and also each crude oil and the corrosion rates of those metals were determined by weight loss method while observing the corroded surface under the microscope and 
cleaning with the aid of sand papers and isooctane. The same procedure was repeated up to another two sets of metal pieces after 30 and 45 days from the immersed day.

The rate of corrosion in each metal piece was determined by the weight loss method. This is one of simplest method which can be implemented with a few of reading of corroded metal pieces. The most important readings are the initial weight of cleaned metal piece before the immersion in crude oils and the final weight of metal piece after cleaning the corroded surface $[9,10]$. The mathematical expression and terms of weight loss method are given in the Eq. (1).

$$
\mathrm{CR}=\mathrm{W} \cdot \mathrm{k} /(\mathrm{D} \cdot \mathrm{A} \cdot \mathrm{t})
$$

where $\mathrm{W}$ - weight loss due to the corrosion in grams $\mathrm{k}=$ const $(22,300)$; $\mathrm{D}$ - metal density in $\mathrm{g} / \mathrm{cm}^{3}$; $\mathrm{A}$ - area of metal piece $\left(\mathrm{inch}^{2}\right) ; \mathrm{t}$ - time (days); $\mathrm{CR}$ - corrosion rate of metal piece.

Due to the requirement of the comparison of corrosion rates in different metals, the dimensions and shape of each metal piece was wielded similarly.

The surface of each metal piece was observed under the 400X lens of the optical microscope before the immersion in crude oils and after corroded.

The Fe concentrations in crude oil samples which are exposed to the carbon steels and stainless steels were tested by the atomic absorption spectroscopy (AAS) while testing the $\mathrm{Cu}$ concentration of crude oil samples which are exposed to the Monel metal as a confirmation step of the reaction between metals and crude oils. In the sample preparation, $1 \mathrm{ml}$ of each crude oil sample was diluted with $9 \mathrm{ml}$ of 2-propanol and filtered.

The hardness of each metal was tested before the immersion of crude oils and after the corrosion by the Vicker's hardness tester.

\section{Results and discussion}

The tested corrosive properties of both crude oils are given in the Table 2.

Table 2

Corrosive properties of crude oils

\begin{tabular}{ccc}
\hline Corrosive property & Murban & Das Blend \\
\hline Sulfur content (wt. \%) & 0.758 & 1.135 \\
Salt content (ptb) & 4.4 & 3.6 \\
Acidity (mg KOH/g) & 0.01 & 0.02 \\
Mercaptans (ppm) & 25 & 58
\end{tabular}

According to the results regarding the corrosive properties of both crude oils, Das Blend contained higher amount of sulfur, acidity and mercaptans while containing lower amount of salt than Murban. The sulfur content is much considerable factor regarding metallic corrosion with the aid of water present in crude oils at some high temperatures $[2,6,13]$. The reaction regarding the corrosion is given in the Eq. (2).

$$
8 \mathrm{Fe}+\mathrm{S} 8 \rightarrow 8 \mathrm{FeS} .
$$

Due to the presence of organic acids in crude oils, those crude oils show the property of corrosive $[2,4,12,15]$. Because those acids are consisted with "RCOOH" and it tends to cause the oxidization of Fe. The chemical reactions of acidic corrosion are given in the Eq. 3-5.

$$
\begin{gathered}
\mathrm{Fe}+2 \mathrm{RCOOH} \rightarrow \mathrm{Fe}(\mathrm{RCOO})_{2}+\mathrm{H}_{2}, \\
\mathrm{FeS}+2 \mathrm{RCOOH} \rightarrow \mathrm{Fe}(\mathrm{COOR})_{2}+\mathrm{H}_{2} \mathrm{~S},
\end{gathered}
$$




$$
\mathrm{Fe}(\mathrm{COOR})_{2}+\mathrm{H}_{2} \mathrm{~S} \rightarrow \mathrm{FeS}+2 \mathrm{RCOOH} .
$$

Apart from that, mercaptans are the compound of sulfur which is highly involved in the metallic corrosion also called "sulfidation" although dependable on the conditions of the temperature. According to the results of most of past researches, a proper involvement of mercaptans regarding the metallic corrosion, have been found at high temperatures beyond $230 \mathrm{C}$.

Salts play a huge role in metallic corrosion that due to the ability of breaking into $\mathrm{HCl}$ by reacting with the water at some higher temperatures [2, 7]. Those $\mathrm{HCl}$ tend to behave as corrosive compound and contribute on the formation of metal sulfides as explained in the Eq. (6)-(8).

$$
\begin{gathered}
\mathrm{CaCl}_{2}+\mathrm{H}_{2} \mathrm{O} \rightarrow \mathrm{CaO}+2 \mathrm{HCl}, \\
\mathrm{HCl}+\mathrm{Fe} \rightarrow \mathrm{FeCl}_{2}+\mathrm{H}_{2}, \\
\mathrm{FeCl}_{2}+\mathrm{H}_{2} \mathrm{~S} \rightarrow \mathrm{FeS}+2 \mathrm{HCl} .
\end{gathered}
$$

When comparing the contents of corrosive compounds in both crude oils, Das Blend may have some higher tendency of causing the corrosion than Murban based on the assumption that each corrosion process was occurred in proper way in the experiment background although it can be explained clearly in the further discussion.

According to the readings of the XRF detector, the chemical compositions of used metals

\begin{tabular}{|c|c|c|c|}
\hline Metal & $\mathrm{Fe}(\%)$ & Ni (\%) & $\mathrm{Cu}(\%)$ \\
\hline Carbon steel (High) & 98.60 & 0.17 & 0.37 \\
\hline Carbon steel (Medium) & 99.36 & - & - \\
\hline $\begin{array}{c}\text { Carbon steel } \\
\text { (Mild } \\
\text { steel) }\end{array}$ & 99.46 & - & - \\
\hline $\begin{array}{l}\text { 410-MN:1.8 420-MN:2.8 } \\
\quad \text { (Stainless steel) }\end{array}$ & 88.25 & 0.18 & 0.10 \\
\hline $\begin{array}{l}\text { 410-MN:1.7 420-MN:1.7 } \\
\text { (Stainless steel) }\end{array}$ & 87.44 & - & - \\
\hline $\begin{array}{l}\text { 321-MN:1.4 304-MN:1.9 } \\
\text { (Stainless steel) }\end{array}$ & 72.47 & 8.65 & - \\
\hline Monel 400 & 1.40 & 64.36 & 33.29 \\
\hline
\end{tabular}
are given in the Table 3 .

Table 3

Chemical compositions of metals

According to the composition of metals, the Fe percentages are high in the first three types of metals which are known as carbon steels while fourth, fifth and sixth types of metals are having moderate amount of Fe which are known as stainless steel. The seventh metal type consisted with trace amount of $\mathrm{Fe}$ while $\mathrm{Ni}$ is becoming into the major element $[1,3,5,6]$.

The average corrosion rates of metals with respect to the both crude oils are given in the Tables 4, 5 . 
Table 4

The corrosion rates of metals in Murban crude oil

\begin{tabular}{|c|c|c|c|c|}
\hline Metal & 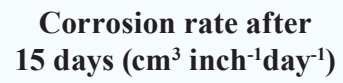 & $\begin{array}{l}\text { Corrosion rate after } \\
30 \text { days }\left(\mathrm{cm}^{3} \text { inch }^{-1} \text { day }^{-1}\right)\end{array}$ & 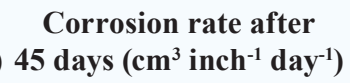 & $\begin{array}{l}\text { Average corrosion rate } \\
\left(\mathrm{cm}^{3} \text { inch }^{-1} \text { day }^{-1}\right)\end{array}$ \\
\hline (1) Carbon Steel (High) & 0.811971 & 0.466425 & 0.068794 & 0.4490632 \\
\hline $\begin{array}{l}\text { (2) Carbon Steel } \\
\text { (Medium) }\end{array}$ & 0.817791 & 0.180339 & 0.073358 & 0.3571623 \\
\hline $\begin{array}{l}\text { (3) Carbon Steel } \\
\text { (Mild steel) }\end{array}$ & 0.10973 & 0.048244 & 0.038592 & 0.0655217 \\
\hline $\begin{array}{l}\text { (4) } 410-\mathrm{MN}: 1.8 \\
420-\mathrm{MN}: 2.8 \\
\text { (Stainless steel) }\end{array}$ & 0.041784 & 0.016075 & 0.011801 & 0.02322 \\
\hline $\begin{array}{l}\text { (5) } 410-\mathrm{MN}: 1.7 \\
420-\mathrm{MN}: 1.7 \\
\text { (Stainless steel) }\end{array}$ & 0.11626 & 0.011968 & 0.007574 & 0.0452676 \\
\hline $\begin{array}{l}\text { (6) 321-MN:1.4 } \\
\text { 304-MN:1.9 } \\
\text { (Stainless steel) }\end{array}$ & 0.016612 & 0.007453 & 0.005599 & 0.009888 \\
\hline (7) Monel 400 & 0.356263 & 0.034877 & 0.026729 & 0.13929 \\
\hline
\end{tabular}

Table 5

The corrosion rates of metals in Das Blend crude oil

\begin{tabular}{|c|c|c|c|c|}
\hline Metal & $\begin{array}{c}\text { Corrosion rate after } \\
15 \text { days }\left(\mathrm{cm}^{3} \text { inch }^{-1} \text { day }^{-1}\right)\end{array}$ & $\begin{array}{l}\text { Corrosion rate after } 30 \\
\text { days }_{\left(\mathrm{cm}^{3} \text { inch }^{-1} \text { day }^{-1}\right)}\end{array}$ & 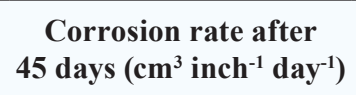 & $\begin{array}{l}\text { Average corrosion rate } \\
\qquad\left(\mathrm{cm}^{3} \text { inch }^{-1} \text { day }^{-1}\right)\end{array}$ \\
\hline (1) Carbon Steel (High) & 0.350249 & 0.224901 & 0.024738 & 0.1999627 \\
\hline $\begin{array}{l}\text { (2) Carbon Steel } \\
\text { (Medium) }\end{array}$ & 0.481055 & 0.140654 & 0.05911 & 0.2269396 \\
\hline $\begin{array}{l}\text { (3) Carbon Steel } \\
\text { (Mild steel) }\end{array}$ & 0.162883 & 0.141093 & 0.100635 & 0.1348702 \\
\hline $\begin{array}{l}\text { (4) } 410-\mathrm{MN}: 1.8 \\
420-\mathrm{MN}: 2.8 \\
\text { (Stainless steel) }\end{array}$ & 0.044146 & 0.034035 & 0.006149 & 0.0281102 \\
\hline $\begin{array}{l}\text { (5) } 410-\mathrm{MN}: 1.7 \\
420-\mathrm{MN}: 1.7 \\
\text { (Stainless steel) }\end{array}$ & 0.053701 & 0.034841 & 0.016363 & 0.0349681 \\
\hline $\begin{array}{l}\text { (6) 321-MN:1.4 } \\
\text { 304-MN:1.9 } \\
\text { (Stainless steel) }\end{array}$ & 0.022894 & 0.006503 & 0.002825 & 0.0107404 \\
\hline (7) Monel 400 & 0.061554 & 0.037655 & 0.016067 & 0.0384254 \\
\hline
\end{tabular}

Above results showed that there were higher rates of corrosion in first three types of metals and relatively lower corrosion rates were found from fourth, fifth and sixth types of metals while seventh type of metal is showing a moderate corrosion rate. Based on the type of crude oils, four types of metals were shown higher rate of corrosion in Murban crude oil than the corrosion rates of those same metals in Das Blend crude oil even though Das Blend is consisting higher amount of corrosive compounds than the Murban. According to results there can be concluded that the effect of salt in the metallic corrosion is stronger than the contribution of sulfur content, acidity and mercaptans content altogether. It can be concluded that there wasn't happened some "sulfidation" process properly at the room temperature. Usually the acids do not need particular 
temperature for the cause of corrosion although the effectiveness of salt in the crude oils was became as a decisive factor for the corrosion in most of occasions $[2,9,12,13,15]$. However there were seen that some acceptable relationship between the Fe concentration of metals and the corrosion rate. Because carbon metals showed higher corrosion rates while stainless steel are showing lower corrosion rates [1-5].

According to the microscopic analysis a corroded metallic surface of a stainless steel is given in the Fig. 3, 4.

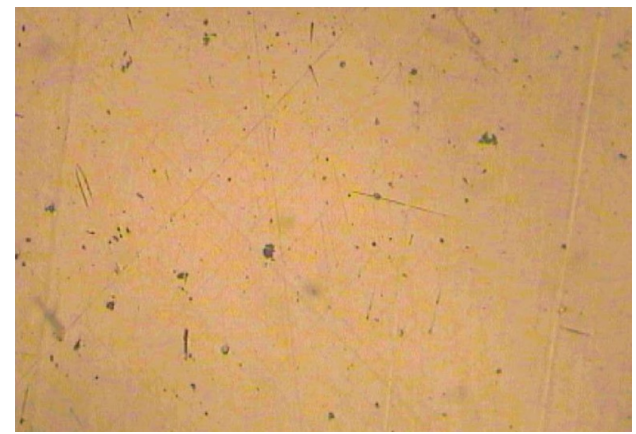

Fig. 3. Plain surface of mild steel

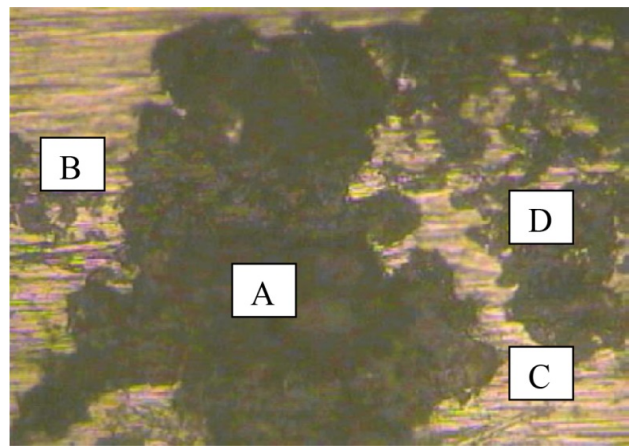

Fig. 4. Corroded surface of the same mild steel piece: A - Black color compound and trace compounds; B - Cavities, C - Cracks with corrosion and D- Rusty color compounds in scruple

According to the visible appearances of corrosion compounds, some important features were identified as a qualitative analysis of the corrosion.

The identifications of those compounds were based on the physical appearances of those compounds such as the color $[1,3,5]$. A descriptive summary of corrosion compounds are given in the Table 6.

Table 6

Descriptive summary of the corrosion compounds

\begin{tabular}{ccc}
\hline Compound & Appearances & Observations \\
\hline $\mathrm{FeS}$ & Black, Brownish black, Powder, Pitting, Cracks & Observed most of features from each metal \\
$\mathrm{Fe}_{2} \mathrm{O}_{3}$ & Rusty color & Observed rarely \\
$\mathrm{CuS}$ & Darkindigo/dark blue & Difficult to distinguish
\end{tabular}

By referring above information there can be suggested that the corrosion was happened on most of metals with respect to both crude oils in most of occasions. Apart from that some cavities and cracks were identified specially on the surfaces of stainless steels.

According to the atomic absorption spectroscopic (AAS) analysis the Fe and $\mathrm{Cu}$ concentrations of crude oil samples are given in the Table 7. 
Table 7

Analysis of the $\mathrm{Fe}$ and $\mathrm{Cu}$ concentrations of crude oil samples

\begin{tabular}{|c|c|c|c|}
\hline Metal & Crude oil & Fe concentration/ppm & $\mathrm{Cu}$ concentration/ppm \\
\hline \multirow{2}{*}{ Carbon steel (High) } & Murban & 0.47 & - \\
\hline & Das Blend & 1.10 & - \\
\hline \multirow{2}{*}{ Carbon steel (Medium) } & Murban & 0.54 & - \\
\hline & Das Blend & 0.02 & - \\
\hline \multirow{2}{*}{ Carbon steel (Mild Steel) } & Murban & -0.08 & - \\
\hline & Das Blend & -0.48 & - \\
\hline \multirow{2}{*}{$\begin{array}{l}\text { 410-MN:1.8 420- MN:2.8 } \\
\text { (Stainless steel) }\end{array}$} & Murban & -0.65 & - \\
\hline & Das Blend & -0.78 & - \\
\hline \multirow{2}{*}{$\begin{array}{l}\text { 410-MN:1.7 420-MN:1.7 } \\
\text { (Stainless steel) }\end{array}$} & Murban & -0.71 & - \\
\hline & Das Blend & -0.79 & - \\
\hline \multirow{2}{*}{$\begin{array}{l}\text { 321-MN:1.4 304-MN:1.9 } \\
\text { (Stainless steel) }\end{array}$} & Murban & -0.44 & - \\
\hline & Das Blend & -0.17 & - \\
\hline \multirow{2}{*}{ Monel 400} & Murban & - & 10.47 \\
\hline & Das Blend & - & 9.49 \\
\hline
\end{tabular}

Based on the invisible weight losses of metal pieces this test was performed. The AAS results showed some significant concentration of $\mathrm{Fe}$ in both crude oils that exposed to the first two types of carbon steels also showed highest corrosion rates in both crude oils. There wasn't found the presence of $\mathrm{Fe}$ in any type of stainless steel while finding an excess concentration of $\mathrm{Cu}$ from both crude oils that exposed to the Monel metal which was also shown moderate corrosion rate. Those observations can also be used as the confirmation of the cause of corrosion. The corrosion is known as the formation of metallic oxide, sulfide, hydroxide or another certain compound. After formation of corrosion those relevant compounds tend to remove from the metal surface due to the attractive and repulsive forces in between successive electrons and protons [1, 3].

The variations of hardness in each metal piece with respect to each crude oil are given in the Tables $8,9$.

Table 8

Variations of the hardness of metals in Murban

\begin{tabular}{lcc}
\hline \multicolumn{1}{c}{ Metal } & Initial hardness (HV) & Hardness after the corrosion (HV) \\
\hline Carbon steel (High) & 267.63 & 254.93 \\
Carbon steel (Medium) & 215.2 & 200.35 \\
Carbon steel (Mild Steel) & 265.85 & 244.23 \\
410-MN:1.8 420-MN:2.8 (Stainless steel) & 207.43 & 194.78 \\
410-MN:1.7 420-MN:1.7 (Stainless steel) & 184.5 & 190.2 \\
321-MN:1.4 304-MN:1.9 (Stainless steel) & 225.13 & 213.62 \\
Monel 400 & 269.3 & 248.375
\end{tabular}


Table 9

Variations of the hardness of metals in Das Blend

\begin{tabular}{lcc}
\hline \multicolumn{1}{c}{ Metal } & Initial Hardness $(\mathbf{H V})$ & Hardness after the corrosion (HV) \\
\hline Carbon steel (High) & 267.63 & 254.2 \\
Carbon steel (Medium) & 215.2 & 194.75 \\
Carbon steel (Mild Steel) & 265.85 & 226.1 \\
410-MN:1.8 420-MN:2.8 (Stainless steel) & 207.43 & 188.58 \\
410-MN:1.7 420-MN:1.7 (Stainless steel) & 184.5 & 171.23 \\
321-MN:1.4 304-MN:1.9 (Stainless steel) & 225.13 & 201.1 \\
Monel 400 & 269.3 & 255.48
\end{tabular}

According to the results regarding the hardness values of metal pieces before and after the corrosion there were identified slight reduction of hardness in each metal piece with respect to each crude oil. After formation of corrosion on the metal surface those compounds are being in the state of discarding from the relevant metal surface while causing some instability on the metal surface $[1,3,5]$. The reduction of the hardness also can be used as a primary confirmation evidence for the corrosion.

These obtained results showed the self corrosive protection layer of the stainless steels can be recommended as a solution for the corrosion also this research can be further developed in several ways. Because there may be some experimental errors such as the temperature variations, some errors in the determinations of the corrosion rates of metals under the manual method and some errors in the microscopic analysis.

\section{Conclusion}

According to the obtained results, Das Blend crude oil was composed with higher amount of sulfur, mercaptans and acidity while containing lower amount of salts than Murban crude oil although there were identified higher rates of corrosion in four types of metals against Murban crude oil than Das Blend crude oil. Therefore, it can be concluded the cause of corrosion due to the salt presence in crude oil is much stronger than the cause of corrosion due to the sulfur, mercaptans and acids presence in crude oils at the room temperature. The improper reactions of sulfur compounds at the room temperature also can be demonstrated with obtained results. According to the qualitative analysis the formation of $\mathrm{FeS}$ was observed with respect to the visible appearances. Altogether with the results regarding $\mathrm{Fe}$ and $\mathrm{Cu}$ concentrations in AAS analysis and the reduction of hardness in corroded metals provided reasonable evidences for the cause of corrosion forever.

\section{Appendices}

According the obtained results and the gained experiences there can be recommended some further works in advanced way as given in the below.

- The analysis of the formed corrosion compounds that observed under the microscope by some advanced compositional analysis method such as X-ray diffraction (XRD).

- The determination the corrosion rate by using some newly developed digital instrument instead of the weight loss method or performed both methods in a same experiment.

- The analysis of the real effects of both elemental sulfur and active sulfur compounds at some higher temperatures as they required and investigate the optimal temperature which there can be found highest corrosion rates with respect to each metal in each crude oil.

- The analysis of the decay of metallic elements into crude oils can be extended up to several elements that composed in such metals rather than ferrous and copper by the same methodology of atomic absorption spectroscopic analysis (AAS). 


\section{Acknowledgment}

The great contribution of the staff of laboratory including technical and administration on the current research works must be mentioned and appreciated.

\section{References}

[1] Khana, O. P. (2009). Materials Science and Metallurgy. New Delhi: Dhanpet Rai and Sons publication.

[2] Fahim, M. A., Alsahhaf, T. A., Elkilani, A. (2010). Fundamentals of Petroleum Refining. Elsevier, 516. doi: https://doi.org/10.1016/c2009-0-16348-1

[3] Calister, W. D. (2003). An Introduction of Materials Science and Engineering. New York: John Wiley and Sons, 820 .

[4] Davis, M. E., Davis, R. J. (2003). Fundamentals of Chemical Reaction Engineering. New York: McGraw-Hill.

[5] Singh, R. (2006). Introduction to Basic Manufacturing Process and Engineering Workshop. New Delhi: New Age International Publication, 475.

[6] Bolton, W. (1993). Engineering Materials Technology. Elsevier, 468. doi: https://doi.org/10.1016/ c2013-0-04622-1

[7] Ajimotokan, H. A., Badmos, A. Y., Emmanuel, E. O. (2009). Corrosion in Petroleum Pipelines. New York Science Journal, 2 (5), 36-40.

[8] Speight, J. G. (1999). The Chemistry and Technology of Petroleum. Boca Raton, 934. doi: https:// doi.org/10.1201/9780824742119

[9] Afaf, G. A. (2007). Corrosion Treatment of High TAN Crude. Khartoum.

[10] Okpokwasili, G. C., Oparaodu, K. O. (2014). Comparison of Percentage Weight Loss and Corrosion Rate Trends in Different Metal Coupons from two Soil Environments. International Journal of Environmental Bioremediation \& Biodegradation, 2 (5), 243-249.

[11] Usman, A. D., Okoro, L. N. (2015). Mild Steel Corrosion in Different Oil Types. International Journal of Scientific Research and Innovative Technology, 2 (2), 9-13.

[12] Ahmed, I. M., Elnour, M. M., Ibrahim, M. T. (2014). Study the Effects of Naphthenic Acid in Crude Oil Equipment Corrosion. Journal of Applied and Industrial Sciences, 2 (6), 255-260.

[13] Rickard, D., Luther, G. W. (2007). Chemistry of Iron Sulfides. Chemical Reviews, 107 (2), 514562. doi: https://doi.org/10.1021/cr0503658

[14] Fang, H., Nesic, S., Young, D. (2008). Corrosion of Mild Steel in the Presence of Elemental Sulfur. International Corrosion Conference and Expo.

[15] Bota, G. M., Nesic, S., Qu, D., Wolf, H. A. (2010). Naphthenic Acid Corrosion of Mild Steel in the Presence of Sulfide Scales Formed in Crude Oil Fractions at High Temperature. International Corrosion Conference and Expo. 